\title{
Evaluation of Tissue Factor -603 A/G Promoter Gene Polymorphism in Thrombotic Processes in Patients with Antiphospholipid Syndrome
}

\author{
Antifosfolipid Sendromunda Doku Faktörü Düzeyi ve Doku Faktörü Promotor \\ Bölge -603a/g Polimorfizminin Değerlendirilmesi
}

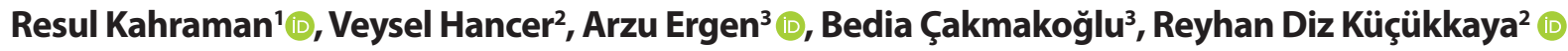 \\ 'Department of Gastroenterology, Umraniye Training and Research Hospital, Health Sciences University, İstanbul, Turkey \\ 2Department of Internal Medicine, İstanbul University, İstanbul School of Medicine, İstanbul, Turkey \\ ${ }^{3}$ Department of Molecular Medicine, İstanbul University Aziz Sancar Institute of Experimental Medicine, İstanbul, Turkey
}

Cite this article as: Kahraman R, Hançer V, Ergen A, Çakmakoğlu B, Diz Küçükkaya R. Evaluation of tissue factor -603 A/G promoter gene polymorphism in thrombotic processes in patients with antiphospholipid syndrome. Experimed 2019; 9(1): 1-6.

\begin{abstract}
Objective: Major clinical manifestations of Antiphospholipid syndrome (APS) are trombosis and thrombosis related complications. Tissue factor (TF) serves primary initiatory of the in vivo coagulation. TF gene expression may be induced in endothelial cells to initiate thrombus formation. In this study, we investigated the frequency of TF $603 \mathrm{~A} / \mathrm{G}$ promoter gene polymorphism in patients with antiphospholipid syndrome (APS) and its effects on TF expression and thrombotic events.
\end{abstract}

Materials and Methods: This study included 64 patients with APS (APS patient with thrombosis arterial and venous $(n=38)$, antiphospholipid antibody-positive patients without thrombosis $(n=26)$ and 44 healthy controls (HCs). Plasma TF levels and antiphospholipid antibodies were measured by ELISA method. Lupus anticoagulant was measured by activated partial thromboplastin time and kaolin clotting time. TF-603 A/G polymorphism was investigated by PCR method.

Results: Our results have showed that patients with APS, TF levels were found in patients significantly higher than the healthy control group ( $p: 0.006, p<0.001$, respectively). Compared between the two patient groups, TF level was significantly higher in the patient with thrombosis group compared to the patient without thrombosis group (p: 0.027).

Conclusion: In this study, we suggest that thrombotic complications observed in patients with APS are associated with increased TF expression.

Keywords: aPLA, antiphospholipid antibodies, APS, antiphospholipid syndrome, TF, tissue factor
Öz

Amaç: Tromboz antifosfolipid sendromu (AFS), tromboz ve tromboz ilişkili komplikasyonlarda majör klinik belirtiler rolündedir. Doku faktörü (DF) in vivo koagulasyonu başlatan temeli oluşturmaktadır. Doku faktörü (DF) ekspresyonu endotelyal hücrelerde trombozu açıklamak için yolunun tetiklenmesinde etkili olabileceği düşünülmektedir. Bu çalışmada normal bireylerde ve AFS hastalarında plazma DF düzeyleri, DF promotor bölge -603A/G polimorfizminin sıklığı ilişkisi araştııımıştır.

Gereç ve Yöntem: Çalışmamıza 64 AFS hastası, arteriyel ve venöz tromboz geçirmiş AFS hastaları $(n=38)$, antifosfolipid antikorları pozitif olan ancak trombotik atağı olmayan hastalar $(n=26)$ ve sağlıklı kontrol $(n=44)$ yer almaktadır. DF düzeyi ELiSA yöntemiyle çaIışılmıştır. Lupus antikoagülanı aktif parsiyel tromboplastin zamanı ve kaolin pıhtılaşma zamanı ile ölçülmüştür. DF promotor bölge $-603 A / G$ polimorfizmi PCR yöntemiyle incelenmiştir.

Bulgular: Sonuçlarımız AFS'lu hastalarda doku faktörü düzeyinin sağlıklı bireylere kıyasla anlamlı olarak artmış olduğunu göstermektedir ( $p: 0,006, p<0,001$ ). Trombozsuz ve trombozlu AFS hastaları sağlıklı kontrol ile tek tek kıyaslandığında DF düzeylerinin her iki AFS grubunda da anlamlı olarak yüksek olduğu görülmüştür. Trombozu olan ve olmayan AFS hastaları birbirleriyle kıyaslandığında ise trombozlu AFS grubunda DF düzeylerinin istatistiksel olarak anlamlı şekilde yüksek olduğu bulunmuştur (p: 0,027).

Sonuç: Sonuçlarımız AFS'da görülen trombotik komplikasyonlarla DF ekspresyonunun ilişkisi olduğunu desteklemektedir.

Anahtar Kelimeler: aPLA, antifosfolipid antikorlar, APS, antifosfolipid sendromu, TF, doku faktörü 


\section{INTRODUCTION}

Antiphospholipid syndrome (APS) is characterized by arterial and/or venous thrombosis and recurrent fetal loss in the presence of antiphospholipid antibodies (APLA) (1). Thrombosis is the main clinical finding in APS. Several mechanisms have been thought to play a role in the pathogenesis of APS, including increased tissue factor (TF) expression by monocytes and endothelial cells (2-4). Antiphospholipid antibodies (APLA) have been shown to induce upregulation of the TF pathway on platelet function. Studies showed that APLA induces significant increase TF expression, transcription and function (2, 4, 5). Tissue factor is a transmembrane glycoprotein. It plays an important role in the initiation and progression of thrombosis. In normal hemostasis, TF induces coagulation by the way of allosteric activation of factor VII. The TF/ FVIla complex activates FIX and FX and leads to fibrin generation (6). Increased TF synthesis in monocytes and endothelial cells is thought to be a result of the binding of antiphospholipid antibodies to the phospholipid binding protein on the surface of these cells. It has been suggested that antiphospholipid antibodies cause TF upregulation on the cell surface due to signals induced after interaction with specific cell surface receptors (7).

Several promoter gene polymorphism of TF (-1812C/T, -1442G/ C, $-1322 \mathrm{C} / \mathrm{T},-1208 \mathrm{D} / \mathrm{I},-603 \mathrm{~A} / \mathrm{G}$ ve $-21 \mathrm{C} / \mathrm{T}$ ) are described (8). One Study showed that the risk of coronary artery thrombosis is increased in individuals who have TF -603G allele (9). Monocytic TF mRNA expression was found to be significantly higher in carriers of the TF -603G allele (10).

In this study, the frequency of TF 603A / G promoter gene polymorphism, its effect on TF expression and its role in thrombosis were investigated in patients with anti-phospholipid syndrome.

\section{MATERIALS AND METHODS}

This study included 64 patients with APS [APS patient with thrombosis $(n=38)$, antiphospholipid antibody-positive patients without thrombosis $(n=26)]$ and 44 healthy controls (HCs). The diagnosis of APS was made according to the Sapporo criteria and the patients were divided two group according to whether they were thrombosis (1). Local ethics committee approval was obtained. Informed consent was obtained from all participants.

Plasma TF levels and antiphospholipid antibodies were measured by ELISA method. Lupus anticoagulant was measured by activated partial thromboplastin time and kaolin clotting time. TF-603 A/G polymorphism was investigated by PCR method.

\section{Patients with APS with thrombosis}

A total of 38 patients (median age 38,17 to 59; female to male ratio 24:14) were included in this group. 19 patients had arterial thrombosis and 19 patients had venous thrombosis. 32 patients were positive for lupus anticoagulant (LA), anticardiolipin immunoglobulin $\mathrm{G}$ ( $\mathrm{lgG}$ ) was positive in 32 patients and immunoglobulin $\mathrm{M}$ (IgM) was positive in 14 patients. 10 patients had fetal loss during pregnancy and 5 patients had thrombocytopenia.

\section{Patients positive for APLA without thrombosis}

There were 26 patients (median age 36 (24-58) and females: male ratio 26: 0) with a persistent positive APLA or recurrent fetal loss in pregnancy. Eight patients had positive LA positive, 23 patients had anticardiolipin IgG positive and 10 patients had anticardiolipin IgM positive. None of these patients developed thrombotic complications during a 3-year follow-up period. Patients with second or third trimester fetal loss or preeclampsia were not included.

\section{Healthy Control (HCs) group}

The control group comprised 44 healthy people (median age 34 years, female: male ratio 28:16) with no history of autoimmune disease or thrombosis. The healthy control group (HCs) was matched for age and sex with the patients.

\section{Measurements of TF Levels}

The enzyme-linked immunosorbent assay (ELISA) was used to detect TF antigen in plasma samples. The ELISA kit (TF Assaymax; Assaypro, USA) used a mouse monoclonal anti-human TF antibody for antigen capture.

\section{Genotyping}

Genomic DNA had been extracted by using polymerase chain reaction (PCR) template preparation kit (Roche Diagnostics, IN, USA) from venous blood samples. The quantity and quality of DNA in each sample was estimated using UV absorbance and agarose gel electrophoresis. The genotyping of the TF - 603 A/G polymorphism was performed using PCR. A 370 bp long fragment of TF was amplified using 5'-CAT gAg AgA CAT CgC CTC Tgas a 5' primer and 5'-gAC CTA ACA TgT TCT AgC CAg AAg as a $3^{\prime}$ primer to introduce a Mval restriction site. The $P C R$ reaction mixture consisted of $0.1 \mu \mathrm{g}$ genomic DNA, $5 \mathrm{pmol}$ of $5^{\prime}$ and $3^{\prime}$ primer, 1.0 U Taq DNA polymerase, $1 \mu \mathrm{mol} / \mathrm{L} \mathrm{MgCl} 2,200 \mu \mathrm{mol} / \mathrm{L}$ dNTPs, $2 \mu \mathrm{l} 10 \mathrm{X}$ PCR buffer provided by the manufacturer (MBI Fermentas). The PCR cycles were arranged as follows: 5 minute for the initial cycle at $95^{\circ} \mathrm{C}$ followed by 35 cycles of 45 seconds of denaturation at $95^{\circ} \mathrm{C}, 1$ minute of annealing at $56^{\circ} \mathrm{C}$ and 1 minute of extension at $72^{\circ} \mathrm{C}$, followed by a final 5 minute extension step at $72^{\circ} \mathrm{C}$ in a Peltier Thermal Cycler apparatus (PTC-200, MJ Research, Watertown, MA, USA).

\section{Statistical Analysis}

All statistical tests were performed with Statistical Package for Social Sciences analysis program version 15 for Windows (SPSS Inc.; Chicago, IL, USA). Continuous variables were expressed as mean \pm standard deviation and categorical variables as ratio. Pearson chi-square test was used to compare groups according to categorical variables. $p$ values $<0.05$ were interpreted as statistically significant. We detected the differences in the concentrations of and plasma TF between the different genotypes using either Student"s t-test for independent samples or one-way ANOVA. Genetic variation was distributed according to Hardy-Weinberg equilibrium. 


\section{RESULTS}

Demographic data of the patients and healthy control groups are summarized in Table 1. The number of women in the patient group was high because the diagnosis of APS was mostly made after the investigation of recurrent fetal losses. Other features were similar for subgroups.

The genotype distributions and allele frequencies of TF -603A/ $\mathrm{G}$ promoter polymorphisms in patients and HCs are shown in

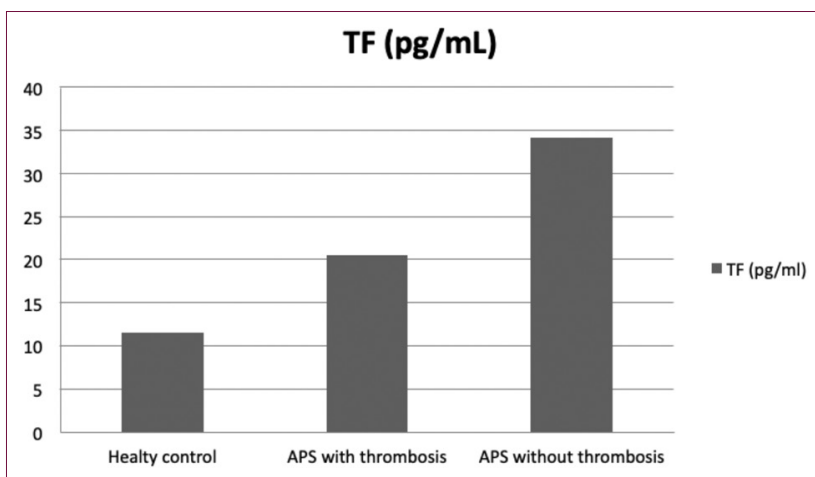

Figure 1. Tissue factor levels in healthy controls and patients with APS

The level of tissue factor was significantly higher in patients with thrombosis with APS than the healthy control group (p: 0.006). Similarly, the level of tissue factor was significantly higher in APS patients without thrombosis than in healthy control group $(p<0.001)$. Tissue factor levels were significantly higher in patients with thrombosis than the group without thrombosis ( $p: 0.027)$

APS: anti phospholipid syndrome; TF: tissue factor
Table 2. In this study, the frequency of TF $-603 \mathrm{~A} / \mathrm{G}$ polymorphism genotype in HCs were as follows; $A A, 38.6 \%$; $A G, 40.9 \%$; GG, 20.5\%. The frequency of alleles was found as; allele A $59.1 \%$ and allele $\mathrm{G} 40.9 \%$. These results were in consistent with the results of other studies. TF - $603 \mathrm{~A} / \mathrm{G}$ polymorphism genotype distributions in patients with APS were AA genotype $29.7 \%$, AG 39\%, GG 31.3\%. We found that TF -603 A/G gene promoter polymorphism showed no statistically significant difference in the context of the frequency of allele and genotype when patients with APS and healthy control groups were compared.

Plasma tissue factor levels were investigated in the patient group and HCs by use of ELISA. The mean TF levels were $11.46 \pm 1.70 \mathrm{pg} / \mathrm{mL}$ in the healthy control group, $20.50 \pm 3.03 \mathrm{pg} /$ $\mathrm{mL}$ in the patients without thrombosis group and $34.11 \pm 5.84$ $\mathrm{pg} / \mathrm{mL}$ in the patients with thrombosis group (Figure 1). TF levels of patients with APS were significantly higher than the HCs (HCs: 11.46 \pm 1.70 ; patient: $28.40 \pm 3.70 \mathrm{p}<0.001$ ). Patients with anti-phospholipid syndrome with and without thrombosis were compared with healthy control group. TF levels of both patient group were significantly higher than the healthy control group ( $\mathrm{p}: 0.006, \mathrm{p}<0.001$, respectively). Compared between the two patient groups, TF level was significantly higher in the patient with thrombosis group compared to the patient without thrombosis group (p:0.027). Extra-thrombotic clinical findings and the levels of antiphospholipid antibodies and TF levels were also investigated in this study. No significant relationship between loss of pregnancy, thrombocytopenia, lupus anticoagulant, aCLA IgM and IgG and TF levels could be found.

Table 1. The main clinical and immunological characteristics of healthy controls and the patients with antiphospholipid syndrome

\begin{tabular}{|c|c|c|c|c|c|}
\hline & $\begin{array}{l}\text { Healty Control } \\
\qquad(n=44)\end{array}$ & $\begin{array}{l}\text { APS patients with } \\
\text { thrombosis }(n=38)\end{array}$ & $\begin{array}{l}\text { APS patients without } \\
\text { thrombosis }(n=26)\end{array}$ & $\begin{array}{l}\text { APS patiens total } \\
\qquad(n=64)\end{array}$ & $\mathbf{p}$ \\
\hline \multirow[t]{2}{*}{ Mean age, $y, \pm S D$} & $34.11 \pm 10.47$ & $38.08 \pm 10.0^{* *}$ & $36.85 \pm 8.41^{*}$ & 37,58 & ${ }^{*} 0.262$ \\
\hline & & & & & $* * 0.085$ \\
\hline Female/Male (n, \%) & $28 / 16(63.6 \%)$ & $24 / 14(63.1 \%)$ & $26 / 0(100 \%)$ & $50 / 14(73 \%)$ & \\
\hline Fetal losses n, women (\%) & - & $10(41.6 \%)$ & 19(73\%) & $29(58 \%)$ & 0.025 \\
\hline Thrombocytopenia & - & $5(13.15 \%)$ & $7(26.9 \%)$ & $12(18.7 \%)$ & 0.066 \\
\hline None & & $33(86.84 \%)$ & $19(73.1 \%)$ & $52(81.2 \%)$ & \\
\hline Mild & & 2 (5.26\%) & 1 (3.9\%) & $3(4.6 \%)$ & \\
\hline Moderate & & $1(2.63 \%)$ & $3(11.5 \%)$ & $4(6.2 \%)$ & \\
\hline Severe & & $2(5.26 \%)$ & $3(11.5 \%)$ & $5(7.8 \%)$ & \\
\hline LA & - & $20(52.6 \%)$ & $8(30.8 \%)$ & $28(43.7 \%)$ & 0.083 \\
\hline ACA IgG & & $33(86.8 \%)$ & $23(88.5 \%)$ & $56(87.5 \%)$ & 0.847 \\
\hline ACA IgM & & $14(36.8 \%)$ & 10 (38.5\%) & 24 (37.5\%) & 0.895 \\
\hline
\end{tabular}


Table 2. TF $603 \mathrm{~A} / \mathrm{G}$ polymorphism genotype and allele frequencies with APS and healthy controls

\begin{tabular}{|c|c|c|c|c|c|}
\hline \multirow[b]{2}{*}{603 A/G polymorphism } & \multicolumn{3}{|c|}{ Genotype } & \multicolumn{2}{|c|}{ Allele } \\
\hline & AA & AG & GG & A & G \\
\hline APS total $(n=64)$ & 19 (29.7\%) & $25(39.1 \%)$ & $20(31.3 \%)$ & $63(49.2 \%)$ & $65(50.8 \%)$ \\
\hline APS with thrombosis $(n=38)$ & $12(31.6 \%)$ & $14(36.8 \%)$ & $12(31.6 \%)$ & $38(50 \%)$ & $38(50 \%)$ \\
\hline Arterial thombosis $(n=19)$ & $7(36.8 \%)$ & $8(42.1 \%)$ & $4(21.1 \%)$ & $22(57.9 \%)$ & $16(42.1 \%)$ \\
\hline Venous thrombosis $(n=19)$ & $5(26.3 \%)$ & $6(31.6 \%)$ & $8(42.1 \%)$ & $16(42.1 \%)$ & $22(57.9 \%)$ \\
\hline APS without thrombosis $(n=26)$ & $7(26.9 \%)$ & $11(42.3 \%)$ & $20(30.8 \%)$ & $25(48.1 \%)$ & $27(51.9 \%)$ \\
\hline Healthy Controls $(n=44)$ & $17(38.6 \%)$ & $18(40.8 \%)$ & $9(20.5 \%)$ & $52(59.1 \%)$ & $36(40.9 \%)$ \\
\hline
\end{tabular}

Table 3. Tissue factor levels according to genotype in patients with APS and healthy controls

\begin{tabular}{lccc}
\hline Genotype & Patient with APS TF $(\mathbf{p g} / \mathbf{m L})$ & Healthy Control TF $(\mathbf{p g} / \mathbf{m L})$ & $\mathbf{p}$ \\
\hline AA & $31.17 \pm 7.74$ & $15.92 \pm 3.51$ & 0.094 \\
\hline AG & $27.60 \pm 5.88$ & $9.7 \pm 2.25$ & 0.008 \\
\hline GG & $26.65 \pm 5.92$ & $6.5 \pm 0.07$ & 0.003 \\
\hline
\end{tabular}

TF: tissue factor; APS: antiphospholipid syndrome

When the patient group was compared with the HCs, TF levels of patient group were found to be significantly higher than that of the HCs in the AG and GG genotypes. When investigated according to genotypes, TF level in AA genotype was $31.17 \mathrm{pg} /$ $\mathrm{mL}$; AG genotype, $27.60 \mathrm{pg} / \mathrm{mL}$; GG genotype, $26.65 \mathrm{pg} / \mathrm{mL}$. TF levels were found to be significantly higher in the heterozygote (AG) (p:0.008) and homozygote (GG) (p:0.003) patients when compared with the HCs (Table 3).

\section{DISCUSSION}

This study evaluate the effects of TF serum level and TF -603 A/G gene polymorphism on disease characteristics in patients with antiphospholipid syndrome. In this study, it was shown that tissue factor levels in patients with the antiphospholipid syndrome were significantly increased compared to HCs. The frequency of TF -603 A/G gene polymorphism was not significantly different between patients with APS and HCs.

The first study of TF levels in antiphospholipid syndrome was conducted in 1997 by Cuadrado et al. (4). In this study, TF levels were significantly higher in patients with APS with thrombosis group. Monocyte-derived TF expression has been thought to play an important role in the pathogenesis of thrombotic events in primer APS. In 1998, Amengual et al. (11) compared TF and tissue factor pathway inhibitor levels in antiphospholipid syndrome patients and HCs. In this study, TF and tissue factor pathway inhibitor levels were significantly higher in the group with antiphospholipid syndrome. In this study, mononuclear cells from HCs were incubated with blood plasma of patients with antiphospholipid syndrome and HCs. TF expression was found to be significantly higher in the group with antiphospholipid syndrome than in the HCs. In a 1999 study conducted by Dobado-Berrios et al. (12), TF mRNA levels in mononuclear cells of patients with the primary antiphospholipid syndrome were investigated. In this study, it was determined that TF mRNA levels in patients with the antiphospholipid syndrome were significantly higher than HCs. Patients with thrombosis group were relatively higher than the patient without thrombosis group. Similar to these studies, in our study, Patients with APS with thrombosis were found to have significantly higher TF levels than patients with APS without thrombosis. These results support that TF pathway plays an important role in the pathogenesis of thrombosis associated with antiphospholipid syndrome.

After understanding of the role of tissue factor in the pathophysiology of thrombosis, it has led to the investigation of TF genetic polymorphisms in thrombosis-related clinical conditions. In the study performed by Arnaud et al. (8), The promoter region of the TF gene (nucleotide 5 to nucleotide sequence -2732) was examined and 6 different polymorphisms (-1812C / T, -1442G / C, -1322C / T, -1208D / - 21C / T) were found. These polymorphisms were evaluated in a study of ECTIM (Etude Cas-Temoins de l'Infarctus du Myocarde), which included 2391 patients, 1191 patients with nonfatal myocardial infarction and 1163 healthy controls (8). In this study, no statistically significant relationship was found between non-fatal coronary thrombosis and promoter region polymorphisms. There are 
few publications on the effect of TF $603 \mathrm{~A} / \mathrm{G}$ polymorphism in the development of thrombosis.

In a study by Oti et al. (9), The effect of TF polymorphism on myocardial infarction was investigated in 793 myocardial infarction patients and 340 healthy control groups. In this study, TF -603 genotypes were found in patients with myocardial infarction; AA 24\%, LV 51\%, GG $25 \%$ and in the healthy control group; AA 30\%, AG 44\% and GG 26\%, respectively. In this study, TF plasma level was found to be higher in patients with TF -603 GG genotype and increased risk of myocardial infarction in subjects carrying G-alleles. Similarly, in our study, TF plasma levels were higher in APS patients with AG and GG genotypes than in healthy controls.

In a study conducted by Reny et al. (10) TF -603 A/G promoter polymorphism and TF gene expression levels in healthy volunteers were investigated. In this study, distribution of TF -603 polymorphism in healthy individuals was found to be AA 32\%, AG 49\%, GG 19\%. TF mRNA and total blood clotting time were assessed at baseline and after 4 hours of lipopolysaccharide incubation. Initial TF mRNA levels were found to be $40 \%$ lower in those carrying the TF -603A haplotype. TF mRNA levels increased by 70 -fold after 4 hours of lipopolysaccharide incubation. However, there was no significant difference between TF $-603 \mathrm{~A} / \mathrm{G}$ polymorphisms at baseline and at the fourth hour in terms of TF levels and total blood clotting time. There are conflicting studies on the effects of TF promoter region polymorphisms on thrombotic processes. In a study by Opstad et al. (13), TF and TF pathway inhibitor gene polymorphisms were investigated in patients with type 2 diabetes mellitus and coronary artery disease. In this study, TF levels in the heterozygous group of TF -603 A/G polymorphism were found to be lower than in homozygous groups. This result has been interpreted as a sign that the heterozygous genotype plays a protective role against thrombosis.

In our study, the genotype frequency of TF $-603 \mathrm{~A} / \mathrm{G}$ polymorphism in the healthy control group was $38.6 \%$ for AA, $40.9 \%$ for AG, $20.5 \%$ for GG; The allele frequency was $59.09 \%$ for the allele and $40.91 \%$ for the $G$ allele. In the APS patient group, AA genotype was $29.7 \%$, AG was $39.1 \%$ and GG was $31.3 \%$. No significant difference was found TF 603 AG polymorphism allele and genotype frequencies between anti-phospholipid syndrome patient group and healthy control group. The genotype frequencies in our study were found to be similar to the genotype ratios reported by Reny, Ott, and Opstad $(9,10,13)$. When the patient group was divided into subgroups as APS patients with thrombosis and APS patients without thrombosis, there was no statistically significant difference in allele and genotype distribution between the two subgroups. Our study also investigated the association of non-thrombotic clinical findings with antiphospholipid antibodies and TF serum levels in patients with APS. There was no correlation between serum TF level and recurrent fetal losses, thrombocytopenia, and presence of lupus anticoagulant.
In conclusion, our results suggest that thrombotic complications observed in APS are associated with increased TF expression. The distribution of TF -603 A/G polymorphism was found to be similar in both APS patients and healthy controls.

Ethics Committee Approval: Ethics committee approval was received for this study from the Ethics Committee of Istanbul University.

Informed Consent: Written informed consent was obtained from the patients who participated in this study.

Peer-review: Externally peer-reviewed.

Author Contributions: Concept - Z.K., B.T., M.B.A., M.K., E.S.I., B.Ç.; Supervision - Z.K., B.T., M.B.A., M.K., E.S.I., B.Ç.; Materials - Z.K., B.T., M.B.A., M.K., E.S.I.; Data Collection and/or Processing - Z.K., B.T., M.B.A., M.K., E.S.I.; Analysis and/or Interpretation - Z.K., B.T., M.B.A., M.K., E.S.I., B.Ç.; Literature Search - Z.K., B.T., M.B.A., M.K., E.S.I. Writing - Z.K., B.T., M.B.A., M.K., E.S.I.; Critical Reviews - Z.K., B.Ç.

Conflict of Interest: The authors have no conflict of interest to declare.

Financial Disclosure: This work was supported by the Research Fund of the University of Istanbul (Project number:T-93/151206) and Turkish Academy of Science-GEBIP (R.D.K./TUBA-GEBIP/2004-15).

Etik Komite Onayı: Bu çalışma için etik komite onayı İstanbul Üniversitesi'nden alınmıştır.

Hasta Onamı: Yazılı hasta onamı çalışmaya katılan hastalardan alınmıştır.

Hakem Değerlendirmesi: Dış bağımsız.

Yazar Katkıları: Fikir - R.K., V.H., A.E., B.Ç., R.D.K.; Denetleme - R.K., V.H., A.E., B.Ç., R.D.K.; Gereçler - R.K., V.H., A.E., B.Ç., R.D.K.; Veri Toplanması ve/veya İşlemesi - R.K., V.H., A.E., B.Ç., R.D.K.; Analiz ve/veya Yorum - R.K., V.H., A.E., B.Ç., R.D.K.; Literatür Taraması - R.K., V.H., A.E., B.Ç., R.D.K.; Yazan - R.K., V.H., A.E., B.Ç., R.D.K.; Eleştirel İnceleme - R.K., V.H., A.E., B.Ç., R.D.K.

Çıkar Çatışması: Yazarlar çıkar çatışması bildirmemişlerdir.

Finansal Destek: Bu çalışma İstanbul Üniversitesi Araştırma Fonu (Proje No: T-93/151206) ve Türk Bilim Akademisi (R.D.K./TUBA-GEBIP/2004-15) tarafından desteklenmiştir.

\section{REFERENCES}

1. Wilson WA, Gharavi AE, Koike T, Lockshin MD, Branch DW, Piette $J C$, et al. International consensus statement on preliminary classification criteria for definite antiphospholipid syndrome: report of an international workshop. Arthritis Rheum 1999; 42: 1309-11. [CrossRef]

2. Kornberg A, Blank M, Kaufman S, Shoenfeld Y. Induction of tissue factor-like activity in monocytes by anti-cardiolipin antibodies. J Immunol 1994; 153: 1328-32.

3. Atsumi T, Khamashta MA, Amengual O, Hughes GR. Up-regulated tissue factor expression in antiphospholipid syndrome. Thromb Haemost 1997; 77: 222-3. [CrossRef] 
4. Cuadrado MJ, López-Pedrera C, Khamashta MA, Camps MT, Tinahones $\mathrm{F}$, Torres $\mathrm{A}$, et al. Thrombosis in primary antiphospholipid syndrome: a pivotal role for monocyte tissue factor expression. Arthritis Rheum 1997; 40: 834-41. [CrossRef]

5. Reverter JC, Tàssies D, Font J, Monteagudo J, Escolar G, Ingelmo $\mathrm{M}$, et al. Hypercoagulable state in patients with antiphospholipid syndrome is related to high induced tissue factor expression on monocytes and to low free proteins. Arterioscler Thromb Vasc Biol 1996; 16: 1319-26. [CrossRef]

6. McVey JH. Tissue factor pathway. Baillieres Clin Haematol 1994; 7: 469-84. [CrossRef]

7. Vega-Ostertag $M$, Casper $K$, Swerlick R, Ferrara D, Harris EN, Pierangeli SS. Involvement of p38 MAPK in the up-regulation of tissue factor on endothelial cells by antiphospholipid antibodies. Arthritis Rheum 2005; 52: 1545-5. [CrossRef]

8. Arnaud, E, Barbalat V, Nicaud V, Cambien F, Evans A, Morrison C, Arveiler $\mathrm{D}$, et al. Polymorphisms in the $5^{\prime}$ regulatory region of the tissue factor gene and the risk of myocardial infarction and venous thromboembolism: the ECTIM and PATHROS studies. Etude Cas-Temoins de I'Infarctus du Myocarde. Paris Thrombosis case-control Study. Arterioscler Thromb Vasc Biol 2000; 20: 892-8. [CrossRef]
Tissue factor -603 A/G Relation Antiphospholipid Syndrome

9. Ilka Ott, Werner Koch, Nicolas von Beckerath, Rene de Waha, Anna Malawaniec, Julinda Mehilli, et al. Tissue factor promotor polymorphism -603 A/G is associated with myocardial infarction. Atherosclerosis 2004; 177: 189-91. [CrossRef]

10. Reny JL, Laurendeau I, Fontana P, Bieche I, Dupont A, Remones V, et al. The TF-603A/G gene promoter polymorphism and circulating monocyte tissue factor gene expression in healthy volunteers. Thromb Haemost 2004; 91: 248-54. [CrossRef]

11. Amengual O, Atsumi T, Khamashta MA, Hughes GR. The role of the tissue factor pathway in the hypercoagulable state in patients with the antiphospholipid syndrome. Thromb Haemost 1998; 79; 276-81. [CrossRef]

12. Dobado-Berrios PM, López-Pedrera C, Velasco F, Aguirre MA, Torres A, Cuadrado MJ. Increased levels of tissue factor mRNA in mononuclear blood cells of patients with primary antiphospholipid syndrome. Thromb Haemost 1999; 82: 1578-82. [CrossRef]

13. Opstad TB, Pettersen AA, Weiss T, Arnesen H, Seljeflot I. Gender differences of polymorphisms in the TF and TFPI genes, as related to phenotypes in patients with coronary heart disease and type-2 diabetes. Thromb J 2010; 8: 7. [CrossRef] 